UDC 343

DOI https://doi.org/10.32782/2524-0374/2019-5/62

\title{
THE IMPORTANCE OF CUSTOMS AUTHORITIES IN THE ECONOMIC SECURITY OF THE COUNTRY
}

\section{ЗНАЧЕННЯ МИТНИХ ОРГАНІВ В ЕКОНОМІЧНІЙ БЕЗПЕЦІ КРАЇНИ}

\author{
Rohatynska N.Z., Candidate of Law, \\ Associate Professor, Head of the Department of Criminal Law and Procedure \\ Ternopil National Economic University
}

This article is devoted to the study of customs authorities, their place and the role of customs authorities in the system of economic security. The problem and concept of customs, foreign economic security have been studied. The place of customs authorities among other state bodies was analyzed, their importance in the economic security of the country was formulated. The definitions of customs security are presented, which means the state of protection of the economic interests of the State in the customs sphere, which makes it possible in various external and internal conditions, regardless of any threats, to ensure: a) the movement of goods and vehicles across the customs border; b) implementation of regulation related to the establishment and collection of taxes and fees; c) application of customs control and customs clearance procedures with application of customs-tariff and non-tariff regulation measures; d) combating smuggling and violations of customs regulations, as well as performing other tasks assigned to customs authorities through effective implementation of customs business. The experience of the leading countries of the world on the formation of customs policy of the state has been analyzed, and detailed legal training of all instruments of customs regulation, a clear definition of procedural aspects has been proposed. Priorities in the activities of customs authorities have been defined, will allow them to ensure effective interaction with the law enforcement agencies of the country with minimum costs and to maximize the efficiency of filling the state budget of the country. The tasks of customs authorities in the field of customs security and protection of national economic interests, as well as the tasks of implementing internationally defined instruments for regulating international trade on the basis of compliance with the framework standards for ensuring security and facilitation of international trade procedures developed by the World Customs Organization with a view to identifying and preventing internal and external threats are highlighted. It is proposed to build on the accumulated experience of the functioning of customs systems of the world, to bring into line the customs security of Ukraine, which would look like a holistic dynamic system.

Key words: customs, customs safety, foreign economic activity, economic security.

Ця стаття присвячена дослідженню митних органів, їх місця та ролі митних органів у системі забезпечення економічної безпеки. Досліджено проблематику та поняття митної, зовнішньоекономічної безпеки. Проаналізовано місце митних органів серед інших державних органів, сформульовано їх значення в економічній безпеці країни. Представлено визначення митної безпеки, під якою розуміється стан захищеності економічних інтересів держави в митній галузі, який дає змогу в різних зовнішніх і внутрішніх умовах, незалежно від будь-яких загроз, забезпечити: а) переміщення через митний кордон товарів і транспортних засобів; б) здійснення митного регулювання, пов'язаного із встановленням та справлянням податків і зборів; в) застосування процедур митного контролю та митного оформлення із застосуванням заходів митно-тарифного і нетарифного регулювання; г) проведення боротьби з контрабандою та порушеннями митних правил, а також виконання інших покладених на митні органи завдань шляхом ефективної реалізації митної справи. Проаналізовано досвід провідних країн світу щодо формування митної політики держави та запропоновано детальне юридичне відпрацювання всіх інструментів регулювання митниці, чітке формування процедурних аспектів. Визначено пріоритети в діяльності митних органів, що надасть їм змогу з мінімальними затратами забезпечити ефективну взаємодію із правоохоронними органами країни та максимізувати ефективність наповнення державного бюджету країни. Виокремлено завдання митних органів у сфері гарантування митної безпеки і захисту національних економічних інтересів, а також завдання щодо імплементації міжнародно-визначених інструментів регулювання міжнародної торгівлі на основі дотримання Рамкових стандартів забезпечення безпеки та спрощення процедур міжнародної торгівлі, розроблених Всесвітньою митною організацією з метою визначення та попередження внутрішніх і зовнішніх загроз. Запропоновано базуватись на накопиченому досвіді функціонування митних систем світу, привести у відповідність митну безпеку України, яка б виглядала б як цілісна динамічна система.

Ключові слова: митниця, митна безпека, зовнішньоекономічна діяльність, економічна безпека.

Foreign economic and customs security are aimed at satisfying the economic interests of the State and are important components of its economic security. Foreign economic and customs security are concepts that intersect but are mutually absorbed. Customs security refers to the state of protection of the economic interests of the State in the customs sphere, which makes it possible in various external and internal conditions, regardless of any threats, to ensure a) the movement of goods and vehicles across the customs border; b) implementation of regulation related to the establishment and collection of taxes and fees; c) application of customs control and customs clearance procedures with application of customs-tariff and non-tariff regulation measures; d) combating smuggling and violations of customs regulations, as well as performing other tasks assigned to customs authorities through effective implementation of the customs case [2].

As the analysis of research shows the problem of protection of economic interests and the development of modern mechanisms of economic and customs security are engaged both domestic and foreign scientists, among which can be noted: P. Pashka, P. Pisny, I. Berezhnyuk, T. Rudu, O. Ivashina, B. Reisberg, L. Lozovsky, E. Tereshchenko, E. Starodubtsev and others.

Purpose of scientific research is to determine the place of customs security of the state in the economic structure, as well as to identify the main problematic directions of development and possible ways of solving them.

In order for the State to fulfill its functions under customs policy, there are measures to influence the relevant group of public relations (tariff and non-tariff measures), and the specific institution of the State is defined by the concept of "customs business". Article. From the Customs Code of Ukraine [3] defines customs business as the procedure of movement of goods and other objects across the customs border of Ukraine, customs regulation related to the establishment of customs duties, customs control procedures and other means of implementing customs policy. The customs case also includes organizational and legal issues of the functioning of customs authorities, which are entrusted with the direct implementation of the customs case in accordance with Part 1 of Article 11 of the Code of Criminal Procedure. The establishment of customs-tariff and non-tariff measures is a composite of actions ensuring foreign economic security, and the implementation of customs rules, procedures and procedures, including those implementing measures to ensure customs policy, collection of taxes and fees, organization of counteraction to customs violation, that is, the implementation of customs case refers to measures that ensure customs security of the state [3;4].

Security needs are related to the desire and desire of the State to achieve a stable and secure State, and include the need 
to protect against economic, environmental, technological, socio-economic and other environmental hazards and confidence that the priority needs of the State and of the individual will be met. Thus, the goal of security is complex and systemic influence on potential and real threats, achieving stable functioning in unstable external and internal conditions, ensuring reduction and identified and neutralization of risk of factors that directly affect both the activity itself and its specificity [1].

Customs policy, acting as an integral part of domestic and foreign state policy, is formed and introduced based on objective analysis. The definition of the concept of customs security and related categories (customs danger, threat, call, influence, risk and damage) makes it possible to reveal in more detail the system of concepts related to foreign economic and economic security, as well as to define a clear system of actions of the subject of customs security - customs service of Ukraine and other state bodies in the direction of prevention and elimination of causes of customs threats. The development of criteria for assessing customs security should be an important scientific task. During the implementation of customs policy, it is necessary to consider the activities of State bodies within the framework of a single institutional mechanism, directing them to carry out specific tasks in this field, with the aim of ensuring national security and protecting the national interests of Ukraine [1].

By clearly defining the components of the assessment of the activities of customs authorities in the implementation of the customs case, it is possible to determine the state of customs security, achieved through the effective implementation of the customs case in the country as a whole. This assessment could form the basis for the development of a Customs Administration action plan and the preparation of analyses and proposals by the Government to adjust its activities. Measuring the level of customs security requires the use of a large set of indicators that provide the basis for conclusions on meeting the above criteria. A specific set of these indicators should be identified in the economic analysis process in each of the areas $[5 ; 6]$. In order to define criteria for assessing customs security, the issue of risks as an objective phenomenon should be addressed in a comprehensive manner. Inherently, risk is an event with negative economic consequences that can occur at any time and in unknown sizes. Accurate risk measurement is possible through the use of quantitative analysis techniques. The quantitative value of customs risk can be considered a quantitative assessment of the current danger and the probability of realization of potential customs danger in foreign economic activity, customs ratios, external conditions and the effect of their negative consequences. A conscious possibility of an event with undesirable consequences. It is possible to predict and calculate risk as a multi-component value using statistical and simulation models, analytical method, expert assessments, sensitivity analysis (critical values) and other methods. Closely related to the notion of "risk" is the notion of "damage" If the risk is only a possible negative deviation, the harm is a valid, actual negative deviation. Because of harm, risk is realized by acquiring specific measurable economic traits. A pity is defined as an economic, quantitative category expressing the value of loss, damage, activities or work carried out, and the like. In the general definition, harm is assessed consequences [1].

According to Part 4 of Article 7 the direct manual of implementation state customs affairs is assigned by shopping mall of Ukraine to the central executive authority providing forming and implements the state tax and customs policy. Now such body is the Ministry of Finance of Ukraine. So, the Decree of the President of Ukraine of 08.04.2011 No. 446/2011 approved the Provision on the Ministry of Finance of Ukraine according to which Paragraph 1 the Ministry of Finance of Ukraine it is recognized as principal organ in the system of the central executive authorities on forming and ensuring implementation of the state financial, budget and also tax and customs policy (except administration of taxes, collecting, customs payments and implementation of tax and customs policy) [7].

On the basis of Article 545 the Ministry of Finance of Ukraine sends to shopping mall of Ukraine, coordinates and controls activity of customs, carries out other powers provided by the present Code and other laws of Ukraine, within the powers issues orders, will organize and controls their execution. It is possible to claim that the customs relations arise along with the state and there pass all extents of its development. At early stages of the development the customs affairs were quite primitive character and consisted in collecting a customs tax as security accreditations on roads. Later customs affairs began to regulate purposefully trade activity, limiting or allowing import or export of certain goods. With development of the economic relations and growth of manufactory production when the goods turnover was entered by money, the customs relations considerably became complicated.

By promoting economic policy within the State, the customs authorities at the same time ensured, through various customs measures, the protection of their country from financial and economic attacks by other States, had a direct impact on the development of the foreign economic sphere and filled the State treasury with money. Historical analysis shows that the customs activity of the state concentrates not only on the narrow problem of fulfilling the fiscal task, but also solves a significant complex of socio-economic development issues. In modern times, in carrying out their own functions as defined by customs legislation, customs authorities deal with various issues of public life.

The bodies of the Federal Service of Ukraine take a direct part in the formation of the revenue part of the State budget, protect popular achievements in the field of culture, combat economic crime, stimulate the development of international relations and trade. These bodies are designed to protect the economic interests of national economic actors at all levels, from the State to the economic security of an individual. Despite fiscal function, activity of customs authorities has considerable influence on the social sphere, from the level of replenishment of the state budget taxes, collecting and other monetary receipts an opportunity to cover expenses of social character depends, allocating funds from the budget for the corresponding grants, subsidies, programs, payments of the salary and pensions and so forth. Taking into account the opposition of the authorities to the proceeds and charges of illegal movement of prohibited items, such as narcotic drugs, doubtful medical products, it can be argued that customs officers protect the life and health of the nation [8, p. 104-105].

The diversity of customs authorities and the breadth of their coverage of spheres of public life has a large number of examples, but the most important among others is probably the protection of the economic interests of the State by customs officers. The peculiarities of Ukraine's current internal and external situation, the decline of its economy, military actions and political crisis make it impossible to transfer to national conditions those trade and economic mechanisms designed in other countries in accordance with their conditions and place in the world economy. However, the principles of the "design" of these mechanisms, especially multilateral international harmonization, and the norms formed on this basis should be taken into account in the establishment, development and updating of the customs policy mechanism in Ukraine. During the work it is necessary to take into account the experience of post-socialist countries as well. Therefore, the development of customs policies should be organized with thought.

It must be remembered that the philosophy of foreign policy must be that all political issues must be addressed through the lens of national economic interests. The interests of national producers are the priority of foreign economic policy. They are the largest taxpayers, guarantors of a healthy economy, a 
source of employment in a market economy. Of course, the interests of producers from different sectors of the economy differ, so the relevant government agencies have an effort to give equal opportunity to apply to all economic entities for protection or to demand from public authorities.

In turn, the influence of the economic forces of society on the adoption of legislative acts and decisions of the executive power causes the development of various branches of Ukrainian law on the regulation of foreign economic activity. The SFS bodies of Ukraine should rely on improving the professional skills of their employees, being able to serve citizens competently and quickly, in accordance with the legislation, and also have time to monitor the processes taking place in the country. At the same time, it is very important to approach the issues in a balanced manner: not to overestimate, but also not to underestimate their power on the ground. It is also necessary to work closely with local authorities. The protection of economic interests should be carried out by professionals, not by various kinds of political populists and extremists. Until the government understands this, businessmen and producers will not feel protected not only in external markets, but also in domestic markets [9].
Protecting national interests is a priority for customs authorities. It is useful to take into account the experience of the leading countries of the world and to ensure detailed legal training of all instruments of customs regulation, clear definition of procedural aspects. Setting priorities in the activities will allow customs authorities to ensure effective interaction with law enforcement agencies of the country with minimum costs and to maximize the efficiency of filling the state budget of the country. Thus, there are rather complex tasks for customs authorities in the field of customs security and protection of national economic interests requiring rapid response.

In the future, customs security will continue to be an integral part of the economic security of the State. In this context, the implementation of internationally defined instruments to regulate international trade through compliance with the framework standards for security and facilitation of international trade developed by the World Customs Organization to identify and prevent internal and external threats is key. In other words, the customs security of Ukraine should be based on the accumulated experience of the functioning of customs systems of the world and be a holistic dynamic system.

\section{REFERENCES}

1. Пашко П.В., Пісной П.Я. Митна безпека України. Вісник Національної академії державного управління. 2006. № 15. С. $138-143$.

2. Пашко П.В., Пісной П.Я. Митна політика та митна безпеки України. Фінанси України. 2006. № 1. С. 74-85.

3. Митний кодекс України та нормативно правові акти, що регулюють його застосування: 36 док. / упоряд.: П.В. Пашко, В.П. Науменко. Київ : Знання, 2004. 1173 с.

4. Пашко П., Демченко В., Павлюк В. Заходи митно-тарифного регулювання як складова реалізації митної політики України. Вісник AMCУ. 2005. № 4(28). C. 3-7.

5. Пашко П.В., Скороход О.І. Оцінка митної безпеки держави. Фінанси України. 2005. № 2 (111). С. 101-105.

6. Жаліло Я.Л. Проблеми визначення економічної безпеки в системі забезпечення національної безпеки України. Проблемы обеспечения экономической безопасности : материалы Междунарной науч.-практ. конф., Донецк, 23-24 ноября 2001 г. Донецк : РИА ДонНТУ, 2001. C. $27-28$.

7. Калініченко А.І. Митна безпека як складова національної безпеки України. Право та інновації. 2015. № 2 (10).

8. Про Положення про Міністерство фінансів України : Указ Президента України від 08.04.2011 р. № 446/2011. Офріц. вісник Президента України. 2011. № 11. Ст. 610.

9. Олексієнко Р.Ю. Напрями захисту митними органами економічних інтересів держави у зовнішньоекономічній сфері. Митна політика та актуальні проблеми економічної та митної безпеки України на сучасному етапі : матеріали міжнар. наук.-практ. конфр., м. Дніпропетровськ, 23 листоп. 2007 р. Дніпропетровськ : Акад. мит. служби України, 2008. С. 102-106. 